\title{
Przegląd wybranych koncepcji dysleksji rozwojowej - perspektywa genetyczna, neuropsychologiczna i lingwistyczna
}

\section{A review of selected theories on developmental dyslexia - a genetic, neuropsychological and linguistic perspective}

\author{
Mateusz Rusiniak, Monika Lewandowska \\ Instytut Fizjologii i Patologii Słuchu, Światowe Centrum Słuchu, Naukowe Centrum Obrazowania \\ Biomedycznego, Warszawa/Kajetany
}

Adres autora: Mateusz Rusiniak, Światowe Centrum Słuchu, Naukowe Centrum Obrazowania Biomedycznego, ul. Mokra 17, Kajetany, 05-830 Nadarzyn, e-mail: m.rusiniak@ifps.org.pl

\section{Streszczenie}

Cel: Celem pracy było przedstawienie aktualnych poglądów dotyczących mechanizmów warunkujących dysleksję rozwojową.

Materiał i metody: W pracy przedstawiono podłoże genetyczne dysleksji rozwojowej, a także neuropsychologiczne koncepcje wyjaśniające związek dysfunkcji mózgu z deficytami procesów poznawczych współwystępującymi ze specyficznymi trudnościami w czytaniu (m.in. hipoteza zaburzenia czasowego opracowywania informacji, uwagi wzrokowej, deficytu wielkokomórkowego i móżdżkowego). Ponadto omówiono teorie językowe ze szczególnym uwzględnieniem koncepcji deficytu fonologicznego w dysleksji.

Wyniki: Przegląd istniejących teorii wskazuje, że dysleksja jest zaburzeniem niejednorodnym, uwarunkowanym przez wiele czynników. Istniejące koncepcje nie wykluczają się wzajemnie, a dowodzą jedynie, że u osób ze specyficznymi zaburzeniami czytania stwierdza się różne deficyty poznawcze powiązane ze zmianami anatomicznymi i funkcjonalnymi w strukturach mózgu, takich jak planum temporale, okolica ciemieniowo-potyliczna czy móżdżek.

\footnotetext{
Wnioski: W procesie diagnostyki dysleksji rozwojowej, obok sprawdzenia różnych funkcji językowych, warto uwzględnić również badanie innych procesów poznawczych, takich jak uwaga wzrokowa czy automatyzacja czynności. Pozwoli to dokładnie określić profil funkcjonowania poznawczego dziecka i zastosować optymalny rodzaj terapii.
}

Słowa kluczowe: dysleksja rozwojowa • świadomość fonologiczna • deficyt czasowego opracowania informacji • deficyt wielkokomórkowy • uwaga wzrokowa • deficyt móżdżkowy

\section{Abstract}

Aim of the study: The goal of this study was to show current theories on the mechanisms of developmental dyslexia.

Material and methods: In the present paper authors show a genetic basis of developmental dyslexia and neuropsychological theories accounting for relationships between the brain dysfunction and cognitive impairments co-morbid with the specific reading disorders (e.g. hypotheses of deficits in temporal auditory processing, visual attention, as well as theories of the cerebellar or magnocelluar dysfunction). Moreover, linguistic conceptions of developmental dyslexia were introduced with special consideration of the phonological deficit.

Results: The review of selected hypotheses indicates that developmental dyslexia is multifactorial and heterogeneous disorder. Existing theories on dyslexia are not mutually exclusive but rather show that specific reading disorders coexist with many different cognitive deficits associated with the brain dysfunction. Anatomical and functional changes in the brain of persons with dyslexia mainly concern the planum temporale, the parieto-occipital area and the cerebellum. 
Conclusions: In diagnosis of developmental dyslexia it is worth to take into account not only linguistic functions but also other cognitive processes such as visual attention or automatization. This approach allows to identify a specific profile of cognitive functioning of the child and helps to select an optimal way of treatment.

Key words: developmental dyslexia $\bullet$ phoneme awareness $\bullet$ temporal processing deficits $\bullet$ magnocellular deficit $\bullet$ visual attention • cerebellar deficit

\section{Wstęp}

Dysleksja stanowi poważny problem dla dzieci i młodzieży w wieku szkolnym, występujący u ok. 5-10\% populacji ogólnej [1]. Jeżeli te zaburzenia nie zostaną prawidłowo rozpoznane, skutkują trudnościami szkolnymi oraz innymi problemami natury psychologicznej i społecznej. Dysleksję definiuje się jako specyficzne zaburzenia czytania, których nie można wytłumaczyć obniżonym wiekiem umysłowym dziecka, deficytami sensorycznymi lub nieadekwatnym procesem kształcenia [2]. Deficyt ten przejawia się spowolnieniem tempa czytania, trudnością ze zrozumieniem czytanego tekstu. Często towarzyszą mu również problemy z opanowaniem poprawnej pisowni.

Dysleksja wieku dziecięcego określana jest często jako dysleksja rozwojowa. Termin ten związany jest z możliwością występowania dysleksji (nabytej) także u osób dorosłych, która może być konsekwencją uszkodzenia mózgu. Uważa się, że dysleksja wrodzona ma podłoże genetyczne i jest związana ze zmianami w strukturze i funkcjonowaniu mózgowia, jednakże mechanizmy jej powstawania nie zostały do końca poznane. Niniejszy artykuł stanowi przegląd wybranych poglądów na przyczyny powstawania specyficznych zaburzeń czytania. Można je pogrupować w 3 zasadnicze grupy koncepcji: 1) genetyczne, 2) neuropsychologiczne i 3) językowe.

\section{Koncepcje genetyczne}

Badacze zajmują różne stanowiska w odniesieniu do genetycznej koncepcji źródeł dysleksji. Z jednej strony istnieją prace pokazujące przykłady dziedziczenia zaburzeń czytania, z drugiej strony jednak rozpoznanie dysleksji $\mathrm{u}$ rodzica często bywa problematyczne. Warto tu podkreślić, że pierwsza pełna definicja dysleksji, utworzona przez Światową Federację Neurologów, pojawiła się w roku 1968. Natomiast pierwsze wzmianki o możliwości występowania tychże konkretnych zaburzeń pochodzą z przełomu XIX i XX wieku [3]. Istotny jest również fakt, że dopiero w drugiej połowie XX wieku nauka czytania i pisania stała się ogólnodostępnym obowiązkiem społecznym. Wyeliminowało to w znacznej mierze analfabetyzm jako problem światowy (choć niecałkowicie, gdyż w niektórych krajach Trzeciego Świata nadal istnieją utrudnienia w dostępie do edukacji). Stąd też, na chwilę obecną, badania populacyjne nie są w stanie dostarczyć jednoznacznej odpowiedzi dotyczącej występowania dysleksji u przodków dziecka ze specyficznymi trudnościami czytania.

$\mathrm{Na}$ drugim biegunie badań nad genetycznym podłożem dysleksji jest genomika. Możliwy wydaje się związek występowania dysleksji z genem DCDC2 w chromosomie 6, kodującym białko doublecortin domain containing 2 [4]. Bardzo ciekawym podsumowaniem obecnego stanu wiedzy o genetycznym podłożu dysleksji jest praca Marino i wsp. [5]. Autorzy wykazali związek genu DCDC2 z zaburzeniami pamięci i przetwarzania fonologicznego. Niemniej jednak dalsza analiza pokazała, że połączenie genu DCDC2 i dysleksji zależy od populacji. Autorzy postawili tezę, iż wymieniony gen dużo silniej wiąże się z dysleksją dla języka niemieckiego i włoskiego, których cechą wspólną jest przejrzystość ortografii wynikająca $z$ bezpośredniej relacji fonem-grafem. Dla tej grupy językowej przetwarzanie fonologiczne jest silnie związane ze strukturą języka. Dla innych grup językowych wykazanie związku między genem DCDC2 a dysleksją jest znacznie trudniejsze. Przytoczony przez autorów przegląd piśmiennictwa pokazuje, iż w równym stopniu współwystępowanie tego genu z dysleksją rozwojową jest potwierdzane, jak i negowane. Wyniki badań przeprowadzonych $\mathrm{z}$ udziałem 900 dzieci z różnych krajów Europy wydają się potwierdzać tę teorię [1]. Z umiejętnością czytania często łączony jest gen KIAA0319 związany z chromosomem 6. Silny dowód na rolę tego genu w powstawaniu dysleksji rozwojowej przedstawiła Paracchini i wsp. Zespół ten przebadał ponad 6000 obywateli Wielkiej Brytanii. Natomiast badania prowadzone w Finlandii wykazały, że w populacji osób posługujących się językiem fińskim i podobnymi z dysleksją związany może być gen DYX1C1 (chromosom 15), odpowiedzialny za zmiany w rozwoju mózgu z zakresu przetwarzania wzrokowego i słuchowego, a także pamięć krótkotrwałą [6,7].

Powyższy przegląd jedynie zaznaczył rozległość badań i mnogość teorii. Obraz genetycznego podłoża dysleksji komplikuje również fakt, że to samo miejsce na chromosomie może uczestniczyć zarówno w prawidłowym, jak i zaburzonym procesie czytania. Badania pokazują, iż osoby z dysleksją mają więcej wadliwych alleli występujących w chromosomach 1, 2, 3, 6, 15, 18 [6]. Dlatego mało prawdopodobne jest istnienie pojedynczego genu autosomalnego związanego z zespołem zaburzeń czytania, warunkującego występowanie dysleksji w globalnej populacji.

Dalsze badania genetyczne są zatem niezbędne, aby było możliwe wyjaśnienie mechanizmów dziedziczenia specyficznych zaburzeń czytania. Badania genetyczne powinny objąć możliwie wiele populacji posługujących się różnymi językami, gdyż nadal większość badań z tego zakresu dotyczy grup anglojęzycznych [8]. W piśmiennictwie ewidentnie brakuje przede wszystkim badań genetycznego podłoża zaburzeń czytania w językach słowiańskich oraz azjatyckich.

\section{Koncepcje neuropsychologiczne}

Neuropsychologiczne koncepcje dysleksji dotyczą związków specyficznych zaburzeń czytania z budową i funkcjonowaniem mózgu. Relacji tych poszukuje się $\mathrm{w}$ asymetrii półkul mózgowych, ale wyniki tych badań są niejednoznaczne. Pośmiertne badania mózgu, a także późniejsze 
badania neuroobrazowe osób z dysleksją wykazały nieprawidłową symetrię struktury zwanej planum temporale (PT) zajmującej tylny obszar kory słuchowej $[9,10]$. U większości osób praworęcznych obszar ten jest większy w półkuli lewej niż w prawej [11]. Z kolei u osób, u których rozpoznano dysleksję, oba lateralne PT były stosunkowo duże, co tłumaczono zwiększoną liczbą neuronów w półkuli prawej. Według Geschwinda i Galaburdy [12] uszkodzenie lewej półkuli w okresie płodowym prowadzi do powiększenia odpowiadającego regionu w półkuli przeciwległej. Zatem lezje prenatalne mogą powodować anatomiczne powiększenie rozmiarów struktur prawopółkulowych i symetrię mózgu osób z dysleksją. Pośmiertne badania mózgu przeprowadzone przez Galaburdę i współpracowników [13] ujawniły również obecność ektopii, czyli nieprawidłowości w postaci skupisk niedojrzałych neuronów, które nie znajdują się w typowych dla siebie miejscach wokół styku ciemieniowo-potylicznego. Łączy się to z zaburzeniami normalnych połączeń w mózgu i większą ilością aksonów, które przez spoidło wielkie przedostają się do obszarów homologicznych w drugiej półkuli mózgu.

Hipotezę Geshwinda i Galaburdy weryfikowano, stosując metody neuroobrazowania. Chociaż wiele badań z wykorzystaniem MRI potwierdziło zmniejszoną asymetrię PT w dysleksji, obserwowano również zwiększoną symetrię tego obszaru w lewej półkuli lub brak różnic w wielkości tego regionu między osobami ze specyficznymi zaburzeniami czytania a grupą kontrolną (patrz: praca poglądowa [14]). Habib i Robichon w swoich badaniach $\mathrm{z}$ zastosowaniem MRI również nie potwierdzili zmniejszonej asymetrii planum temporale u osób z dysleksją, natomiast wykazali większą symetrię obszaru ciemieniowego u osób ze specyficznymi zaburzeniami czytania [15]. Interesujące, że podobne obserwacje poczyniono, badając mózg Alberta Einsteina, który był geniuszem matematycznym, a jednocześnie dyslektykiem [16].

Inną metodą, która wraz z upowszechnieniem skanerów o polu indukcji 3T nabiera znaczenia, jest pomiar morfometryczny mózgu oparty na liczbie wokseli (ang. Voxel-Based Morphometry, VBM). Warto przytoczyć najnowszą pracę Richlana i wsp. z 2013 roku [17], którzy wykonali metaanalizę prac wykorzystujących VBM do badania mózgowego podłoża dysleksji. Wykazano, iż dla specyficznych zaburzeń czytania charakterystyczne jest zmniejszenie objętości istoty szarej w prawym zakręcie skroniowym górnym i lewej bruździe skroniowej górnej (których znaczną część stanowi wspomniane wcześniej PT).

Wykazano również pewne cechy istoty białej w mózgu, które mogą być związane z dysleksją. Darki i wsp. [18], którzy wykonali badania $\mathrm{z}$ udziałem 76 dzieci i młodych dorosłych posługujących się językiem szwedzkim, zbadali relację między genami potencjalnie odpowiedzialnymi za dysleksję (DCDC2, DYX1C1, KIAA0319) a zmianami $\mathrm{w}$ istocie białej. Badania te wykazały $\mathrm{z}$ dużym prawdopodobieństwem $(\mathrm{p}<0,0038, \mathrm{z}$ korektą Bonferoniego), iż geny te wpływają na wzrost objętości istoty białej w obszarze skroniowo-ciemieniowym półkuli lewej, obejmującym ośrodek Wernickego.

Ze zmianami w obrębie regionu skroniowo-ciemieniowego u osób ze dysleksją wiąże się koncepcja deficytu czasowego opracowywania informacji słuchowej, sformułowana na początku lat osiemdziesiątych XX wieku przez Tallal [19]. Zgodnie $z$ tą teorią trudności w czytaniu mogą wynikać z zaburzenia umiejętności przetwarzania szybko następujących po sobie dźwięków. Dzieci z dysleksją potrzebowały znacznie dłuższej przerwy niż ich rówieśnicy bez problemów z czytaniem, aby poprawnie podać kolejność dwóch bodźców [20,21]. Nie miały one natomiast trudności z rozpoznawaniem sztucznie wydłużonych (do ok. $80 \mathrm{~ms}$ ) spółgłosek zwartych [22]. Badania z zastosowaniem technik neuroobrazowania wykazały, że percepcja następstwa czasowego zdarzeń u osób bez zaburzeń czytania zlokalizowana jest w lewej półkuli, w tzw. styku skroniowo-ciemieniowym $[23,24]$. Temple i wsp. [25] wykonali badania techniką fMRI u dzieci z dysleksją przed terapią i po terapii, której celem było usprawnienie czasowych aspektów opracowywania informacji. Po treningu wykazano wzrost pobudzenia m.in. w lewym obszarze skroniowo-ciemieniowym, wskutek czego aktywność mózgu osób z dysleksją zaczęła przypominać wzorzec pobudzenia obserwowany zazwyczaj przy braku zaburzeń czytania. Podsumowując, deficyt czasowego opracowywania informacji może prowadzić do zaburzeń w analizowaniu mowy na poziomie fonemów, które w konsekwencji prowadzą do specyficznych trudności w czytaniu.

Inna koncepcja wyjaśniająca mechanizmy dysleksji dotyczy opracowywania informacji w układzie wzrokowym. W latach dziewięćdziesiątych Eden [26] wykazała mniejsze pobudzenie grzbietowej drogi wzrokowej w odpowiedzi na poruszające się bodźce u osób ze specyficznymi zaburzeniami czytania. Odkrycie to dało początek koncepcji dysfunkcji tzw. systemu wielkokomórkowego w dysleksji $[27,28]$. W układzie wzrokowym wyodrębniono dwa względnie niezależnie funkcjonujące systemy: wielkokomórkowy (ang. magnocellular system) oraz drobnokomórkowy (ang. parvocellular system). Około 10\% komórek zwojowych, których aksony przekazują informację z oka do mózgu, jest większe niż pozostałe. Oznacza to, że są bardziej wrażliwe i reagują szybciej w odniesieniu do większej przestrzeni, ale nie są czułe na szczegóły lub kolory. Mają projekcje do pierwszorzędowej kory wzrokowej poprzez warstwy wielkokomórkowe w jądrze kolankowatym bocznym. Grzbietowe pasmo przetwarzania wzrokowego jest zdominowane przez informacje $\mathrm{z}$ systemu wielkokomórkowego. W związku z tym system grzbietowy odgrywa zasadniczą rolę w kierowaniu ruchami gałek ocznych i przekazuje informacje do czołowych pól wzrokowych, wzgórka górnego blaszki czworaczej i móżdżku, które są strukturami zaangażowanymi w kontrolę wzrokowo-ruchową. System wielkokomórkowy jest odpowiedzialny za percepcję ruchu, głębi, lokalizacji przestrzennej i wykazuje dużą czułość na nagłe zmiany bodźca i kontrast jasności. Ponieważ umiejętności te są niezbędne w procesie percepcji i różnicowania liter podczas czytania, spodziewano się, że u osób z dysleksją następuje dysfunkcja systemu wielkokomórkowego. Badania psychofizyczne [29], a także elektrofizjologiczne [30] oraz z zastosowaniem fMRI [31] wykazały mniejszą wrażliwość na ruch i kontrast jasności u osób $z$ dysleksją. W literaturze przedmiotu można jednak znaleźć prace, w których przedstawiono wyniki niepotwierdzające teorii deficytu wielkokomórkowego [32,33].

Na uwagę zasługuje również powiązanie zmian anatomicznych i funkcjonalnych w móżdżku ze specyficznymi 
zaburzeniami czytania. Fawcett i Nicolson stwierdzili, że $\mathrm{u}$ dzieci dyslektycznych następują zaburzenia procesu automatyzacji wielu czynności, nie tylko czytania. Przykładowo, dzieci z dysleksją mają kłopoty z utrzymaniem równowagi, gdy nie koncentrują się wyłącznie na tej czynności. Ponieważ procesy automatyzacji są reprezentowane w móżdżku, sformułowano hipotezę deficytu móżdżkowego w dysleksji [34]. Badania metodą PET wykazały mniejszą aktywność móżdżku u osób z dysleksją podczas uczenia się sekwencji stukania palcami [35]. Ponadto stwierdzono zmiany strukturalne przejawiające się występowaniem większych komórek zarówno w móżdżku, jak i w dolnym jądrze oliwki u osób dorosłych z dysleksją [36]. Inne stwierdzone $\mathrm{w}$ tej grupie nieprawidłowości w budowie anatomicznej mózgu to znacznie mniejsze, w porównaniu z osobami bez zaburzeń czytania, prawe przednie płaty móżdżku, obustronna część trójkątna oraz zmniejszona objętość całego mózgu [37].

Zgodnie z powyższą koncepcją w dysleksji, na skutek dysfunkcji móżdżku, początkowo dochodzi do obniżenia zdolności do automatycznej, a zarazem płynnej artykulacji głosek, co powoduje zwiększenie zasobów poznawczych zaangażowanych w tę czynność. W efekcie następuje spowolnienie procesów automatyzacji umiejętności fonologicznych, których dysfunkcja jest ściśle powiązana $\mathrm{z}$ dysleksją. Móżdżek jest najprawdopodobniej zaangażowany $\mathrm{w}$ różne procesy związane $\mathrm{z}$ czytaniem, np. ruchy oczu, pamięć roboczą czy nabywanie różnych umiejętności i ich automatyzację. Chociaż deficyt móżdżku nie jest główną przyczyną dysleksji, struktura ta prawdopodobnie jest jedną $\mathrm{z}$ wielu, których dysfunkcje stwierdza się w zaburzeniach czytania [38].

\section{Koncepcje językowe}

Trzecią grupę koncepcji wyjaśniających dysleksję stanowią teorie lingwistyczne. Wśród nich bezsprzecznie największe znaczenie ma hipoteza deficytu fonologicznego [39]. Zakłada ona, że podstawowym deficytem w dysleksji jest zaburzenie świadomości fonologicznej, którą definiuje się jako „świadomy dostęp do fonemowego poziomu dźwięków mowy oraz umiejętności poznawczego manipulowania reprezentacjami na tym poziomie" [40, s. 362]. Osoba świadoma fonologicznie potrafi koncentrować się na brzmieniu słów, a nie na ich znaczeniu. Deficyt fonologiczny przejawia się trudnościami z dokonywaniem analizy i syntezy sylabowej, identyfikacją fonemów, z wyszukaniem innego słowa, które zawarte jest w podanym wyrazie, $\mathrm{z}$ utworzeniem nowego słowa poprzez zamianę pierwszej lub ostatniej sylaby na inną, z podaniem innego słowa zaczynającego się na tę samą głoskę co wskazane słowo, z rymowaniem. U osób z dysleksją stwierdza się również zaburzenia pamięci fonologicznej, która jest potrzebna, aby poprawnie odtwarzać i zapamiętywać kolejność głosek. Deficyt ten objawia się trudnościami w wypowiadaniu bądź powtarzaniu dłuższych i trudniejszych słów.

U dzieci z dysleksją często obserwuje się także zaburzenia na poziomie syntaktycznym języka [41]. Ich wypowiedzi bywają niepoprawne pod względem gramatycznym, wskazują na ograniczony słownik i deficyty w rozumieniu struktur syntaktycznych. Dyslektycy mają również kłopoty $\mathrm{z}$ dostępnością nazw, szybkością skojarzeń słownych oraz $\mathrm{z}$ rozumieniem, że dane słowo może mieć różne znaczenie w zależności od kontekstu. Zaburzona bywa ponadto umiejętność wychwytywania z czytanego tekstu informacji, które nie zostały przedstawione w sposób dosłowny. Dzieci z dysleksją mają także problem ze zrozumieniem subtelnych różnic w znaczeniu przymiotników, takich jak np. ładny - piękny.

Powyższy przegląd koncepcji wskazuje, że dysleksja rozwojowa nie jest zaburzeniem jednorodnym oraz jest uwarunkowana wieloma czynnikami. Zasadne jest więc mówienie o różnych poznawczych rodzajach dysleksji. Niektórzy badacze sformułowali nawet teorie o współwystępowaniu dwóch niezależnych dysfunkcji warunkujących dysleksję $[42,43]$. Przykładowo hipoteza podwójnego deficytu zakłada, że u osób ze specyficznymi zaburzeniami czytania obserwuje się deficyt zarówno świadomości fonologicznej, jak i automatyzacji czynności, przejawiający się obniżonym tempem nazywania obiektów [43]. Z kolei inna grupa badaczy wykazała, że trudnościom z czytaniem może towarzyszyć albo tylko deficyt fonologiczny, albo dysfunkcja uwagi wzrokowej, albo oba te zjawiska równocześnie [42]. Ponadto Peyrin i wsp. [44] dostarczyli dowodów na niezależność wyżej wspomnianych zaburzeń na poziomie mózgu. Deficyt fonologiczny przejawiał się zmniejszeniem pobudzenia w lewym dolnym zakręcie czołowym, a obniżony zakres uwagi wzrokowej - w płacikach ciemieniowych obu półkul.

\section{Wnioski}

Analizy mechanizmów dysleksji dokonywane są z różnych perspektyw, począwszy od poszukiwań źródeł tego zaburzenia w genetyce, neurologii, a skończywszy na zaburzeniach procesów poznawczych zaangażowanych w zdolność czytania. W ciągu ostatnich lat udowodniono dziedziczność dysleksji, choć mechanizmy te nie zostały do końca poznane. Dzięki dostępności metod neuroobrazowania wykazano zmiany anatomiczne w mózgach osób ze specyficznymi zaburzeniami czytania, takie jak nieprawidłowa symetria lub różnice $\mathrm{w}$ budowie kory dotyczące planum temporale, okolicy ciemieniowo-potylicznej, szlaku wielkokomórkowego oraz móżdżku. Obecne w piśmiennictwie teorie i dowody empiryczne pokazują jednak, że na tę chwilę nie da się, na poziomie mózgu, wskazać jednoznacznie zmian wyjaśniających przyczyny dysleksji. Dalsze badania prowadzone na dużych grupach, $\mathrm{z}$ zastosowaniem metod neuroobrazownia są zatem niezbędne.

Wielość koncepcji wyjaśniających przyczyny dysleksji wskazuje na zasadność poszukiwań powiązań między jej podłożem genetycznym a budową i funkcjonowaniem mózgu dyslektyków oraz ich procesami poznawczymi. $\mathrm{W}$ tym miejscu warto wspomnieć o projekcie naukowym „Human Brain Project”, który - ze względu na planowane wieloośrodkowe badania $\mathrm{z}$ udziałem mieszkańców różnych krajów europejskich - może wnieść znaczący wkład $\mathrm{w}$ istniejącą wiedzę na temat neurobiologicznych i genetycznych korelatów dysleksji rozwojowej. 
1. Becker J, Czamara D, Scerri TS, Ramus F, Csépe V, Talcott JB i wsp. Genetic analysis of dyslexia candidate genes in the European cross-linguistic NeuroDys cohort. Eur J Hum Genet, 2014; 22(5): 675-80.

2. ICD-10: Klasyfikacja zaburzeń psychicznych i zaburzeń zachowania w ICD-10. Opisy kliniczne i wskazówki diagnostyczne. Warszawa: Vesalius \& IPN; 2000.

3. Hinshelwood J. A case of dyslexia: A peculiar form of word-blindess. The Lancet, 1896; 148(3821): 1451-4.

4. Schumacher J, Anthoni H, Dahdouh F, König IR, Hillmer AM, Kluck N i wsp. Strong genetic evidence of DCDC2 as a susceptibility gene for dyslexia. Am J Hum Genet, 2006; 78(1): 52-62.

5. Marino C, Meng H, Mascheretti S, Rusconi M, Cope N, Giorda R i wsp. DCDC2 genetic variants and susceptibility to developmental dyslexia. Psychiatr Genet, 2012; 22(1): 25-30.

6. Scerri TS, Schulte-Körne G. Genetics of developmental dyslexia. Eur Child Adolesc Psychiatry, 2010; 19(3): 179-97.

7. Dahdouh F, Anthoni H, Tapia-Páez I, Peyrard-Janvid M, Schulte-Körne G, Warnke A i wsp. Further evidence for DYX1C1 as a susceptibility factor for dyslexia. Psychiatr Genet, 2009; 19(2): 59-63.

8. Peterson RL, Pennington BF. Developmental dyslexia. The Lancet, 2012; 379(9830): 1997-2007.

9. Galaburda AM, Sherman GF, Rosen GD, Aboitiz F, Geschwind N. Developmental dyslexia: Four consecutive patients with cortical anomalies. Ann Neurol, 1985; 18(2): 222-33.

10. Humphreys P, Kaufmann WE, Galaburda AM. Developmental dyslexia in women: Neuropathological findings in three patients. Ann Neurol, 1990; 28(6): 727-38.

11. Geschwind N, Levitsky W. Human brain: left-right asymmetries in temporal speech region. Science, 1968; 161(3837): 186-7.

12. Galaburda AM. Dyslexia and development: Neurobiological aspects of extra-ordinary brains. Harvard: Harvard University Press; 1993.

13. Galaburda AM, Kemper TL. Cytoarchitectonic abnormalities in developmental dyslexia: a case study. Ann Neurol, 1979; 6(2): 94-100.

14. Leonard CM, Eckert MA. Asymmetry and dyslexia. Dev Neuropsychol, 2008; 33(6): 663-81.

15. Habib M, Robichon F. Parietal lobe morphology predicts phonological skills in developmental dyslexia. Brain Cogn, 1996; 32: $139-42$.

16. Witelson SF, Kigar DL, Harvey T. The exceptional brain of Albert Einstein. The Lancet, 1999; 353(9170): 2149-53.

17. Richlan F, Kronbichler M, Wimmer H. Structural abnormalities in the dyslexic brain: A meta-analysis of voxel-based morphometry studies: Meta-Analysis Developmental Dyslexia. Hum Brain Mapp, 2013; 34(11): 3055-65.

18. Darki F, Peyrard-Janvid M, Matsson H, Kere J, Klingberg T. Three dyslexia susceptibility genes, DYX1C1, DCDC2, and KIAA0319, affect temporo-parietal white matter structure. Biol Psychiatry, 2012; 72(8): 671-6.

19. Tallal P. Auditory temporal perception, phonics, and reading disabilities in children. Brain Lang, 1980; 9(2): 182-98.

20. Rey V, De Martino S, Espesser R, Habib M. Temporal processing and phonological impairment in dyslexia: effect of phoneme lengthening on order judgment of two consonants. Brain Lang, 2002; 80(3): 576-91.

21. Farmer ME, Klein RM. The evidence for a temporal processing deficit linked to dyslexia: A review. Psychon Bull Rev, 1995; 2(4): 460-93.
22. Fitch RH, Miller S, Tallal P. Neurobiology of speech perception. Annu Rev Neurosci, 1997; 20(1): 331-53.

23. Bernasconi F, Grivel J, Murray MM, Spierer L. Plastic brain mechanisms for attaining auditory temporal order judgment proficiency. NeuroImage, 2010; 50(3): 1271-9.

24. Davis B, Christie J, Rorden C. Temporal order judgments activate temporal parietal junction. J Neurosci, 2009; 29(10): $3182-8$.

25. Temple E, Deutsch GK, Poldrack RA, Miller SL, Tallal P, Merzenich MM i wsp. Neural deficits in children with dyslexia ameliorated by behavioral remediation: Evidence from functional MRI. Proc Nat Acad Sci, 2003; 100(5): 2860-5.

26. Eden GF, VanMeter JW, Rumsey JM, Maisog JM, Woods RP, Zeffiro TA. Abnormal processing of visual motion in dyslexia revealed by functional brain imaging. Nature, 1996; 382(6586): 66-9.

27. Stein J, Walsh V. To see but not to read; the magnocellular theory of dyslexia. Trends Neurosci, 1997; 20(4): 147-52.

28. Stein J. The magnocellular theory of developmental dyslexia. Dyslexia, 2001; 7(1): 12-36.

29. Witton C, Talcott JB, Hansen PC, Richardson AJ, Griffiths TD, Rees A i wsp. Sensitivity to dynamic auditory and visual stimuli predicts nonword reading ability in both dyslexic and normal readers. Curr Biol, 1998; 8(14): 791-7.

30. Livingstone MS, Rosen GD, Drislane FW, Galaburda AM. Physiological and anatomical evidence for a magnocellular defect in developmental dyslexia. Proc Natl Acad Sci, 1991; 88(18): 7943-7.

31. Demb JB, Boynton GM, Heeger DJ. Functional magnetic resonance imaging of early visual pathways in dyslexia. J Neurosci, 1998; 18(17): 6939-51.

32. Johannes S, Kussmaul CL, Münte TF, Mangun GR. Developmental dyslexia: passive visual stimulation provides no evidence for a magnocellular processing defect. Neuropsychologia, 1996; 34(11): 1123-7.

33. Olulade OA, Napoliello EM, Eden GF. Abnormal visual motion processing is not a cause of dyslexia. Neuron, 2013; 79(1): $180-90$.

34. Nicolson RI, Fawcett AJ, Dean P. Developmental dyslexia: the cerebellar deficit hypothesis. Trends Neurosci, 2001; 24(9): 508-11.

35. Nicolson RI, Fawcett AJ, Berry EL, Jenkins IH, Dean P, Brooks DJ. Learning difficulties in dyslexic adults. The Lancet, 1999; 353: $1662-7$.

36. Finch AJ, Nicolson RI, Fawcett AJ. Evidence for a neuroanatomical difference within the olivo-cerebellar pathway of adults with dyslexia. Cortex, 2002; 38(4): 529-39.

37. Eckert MA. Anatomical correlates of dyslexia: frontal and cerebellar findings. Brain, 2003; 126(2): 482-94.

38. Stoodley CJ, Stein JF. Cerebellar function in developmental dyslexia. The Cerebellum, 2012; 12(2): 267-76.

39. Liberman IY. Phonology and beginning reading revisited. Brain Read, 1989; 207-20.

40. Stanovich KE. Matthew effects in reading: Some consequences of individual differences in the acquisition of literacy. Reading Research Quarterly, 1986; 21: 360-407.

41. Oszwa U, Borkowska A. Specyficzne trudności szkolne w opanowywaniu czytania i pisania. W: Borkowska A, Domańska Ł, red. Neuropsychologia kliniczna dziecka. Warszawa: Wydawnictwo Naukowe PWN, 2006. 
42. Bosse ML, Tainturier MJ, Valdois S. Developmental dyslexia: The visual attention span deficit hypothesis, Cognition, 2007; 104(2): 198-230.

43. Wolf M, Bowers PG, Biddle K. Naming-speed processes, timing, and reading: a conceptual review. J Learn Disabil, 2000; 33(4): 387-407.
44. Peyrin C, Lallier M, Démonet JF, Pernet C, Baciu M, Le Bas JF i wsp. Neural dissociation of phonological and visual attention span disorders in developmental dyslexia: FMRI evidence from two case reports. Brain Lang, 2012; 120(3): 381-94. 